Arch. Tierz., Dummerstorf 43 (2000) 3, 287-297 Department of Animal Breeding and Husbandry, Faculty of Animal Science. Agricultural University of Athens,
Greece

JOSEF BIZELIS, ANTONIOS KOMINAKIS, EMMANUEL ROGDAKIS and FOTINI GEORGADOPOULOU

\title{
Genetic parameters of production and reproductive traits in on a farm tested Danish Large White and Landrace swine in Greece
}

\begin{abstract}
Summary
Production and reproductive traits in Danish Landrace (LD) and Large White (LW) swine were analysed by restricted maximum likelihood methods to obtain heritabilities as well as genetic and phenotypic correlations. Production traits were: age, backfat thickness (BT), muscle depth (MD) and the ratio BT/MD, adjusted to standard bodyweight of $85 \mathrm{~kg}$. Reproduction traits were: number of pigs born (NB) and number of pigs weaned (NW) per sow and parity. Heritabilities for age, BT, MD and BT/MD were $0.60,0.44,0.51$ and 0.42 for LD and $0.36,0.44,0.37$ and 0.45 for LW, respectively. Genetic correlations between age and BT were -0.22 in LD and 0.44 in LW. The genetic correlation between age and MD was close to zero in both breeds. Genetic correlation between BT and MD were -0.36 and -0.25 in LD and LW, respectively. Heritabilities for NB were 0.25 in LD and 0.13 in LW while heritabilities for NW were close to zero in both breeds. Genetic correlation between NB and NW was 0.46 and 0.70 in LD and LW, respectively.
\end{abstract}

Key Words: heritability, genetic correlations, phenotypic correlations, fattening, reproductive traits, swine, Greece

\section{Zusammenfassung}

Titel der Arbeit: Genetische Parameter von Produktions- und Reproduktionsmerkmalen bei Schweinen der Rassen Danish Large White und Landrasse untersucht in einem Betrieb in Griechenland

Heritabilitäten sowie phänotypische und genetische Korrelationen einiger Produktions- und Reproduktionsmerkmale bei Schweinen der Rassen Danish Large White (LW) und Landrasse (LD) wurden mit Restricted Maximum Likelihood Methoden geschätzt. Folgende Produktionsmerkmale wurden untersucht: Alter, Rückenspeckdicke (BT), Muskeldicke (MD) und das BT/MD Verhältnis, korrigiert auf ein konstantes Körpergewicht von $85 \mathrm{~kg}$. Folgende Reproduktionsmerkmale wurden untersucht: Wurfgrösse bei der Geburt (NB) und beim Absetzen (NW). Bei den LD-Schweinen wurden Heritabilitätswerte von 0,60 fulr das Alter, 0,44 fur die BT, 0,51 für die MD und 0,42 fur das BT/MD Verhaltnis geschatzt. Die entsprechenden Werte bei den LW-Schweinen waren 0,36 furr das Alter, 0,44 für die BT, 0,37 für die MD und 0,45 für das BT/MD Verhältnis. Die geschätzte genetische Korrelation zwischen dem Alter und der BT betrug $-0,22$ bei den LD- und $-0,44$ bei den LW-Schweinen, wăhrend die entsprechende Korrelation zwischen dem Alter und der MD in beiden Rassen nahe Null lag. Die geschătzte genetische Korrelation zwischen der BT and der MD betrug $-0,36$ bei den LD- und $-0,25$ bei den LW-Schweinen. Die Heritabilitătswerte fur die NB betrug 0,25 bei den LD- und 0,13 bei den LWSchweinen, wăhrend die entsprechenden Werte für die NW bei beiden Rassen gleich Null waren. Zwischen der NB und der NW wurde eine genetische Korrelation von 0,46 bei den LD- und von 0,70 bei den LW-Schweinen ermittelt.

Schlusselworrter: Heritabilităt, genetische Korrelation, phănotypische Korrelation, Produktionsmerkmale, Reproduktionsmerkmale, Schweine, Griechenland

\section{Introduction}

The need of the development of genetic improvement programs for swine in Greece has been widely emphasized by the Ministry of Agriculture early in the $90 \mathrm{~s}$ in an attempt to improve the efficiency of pig industry. This attempt has been supported by 
the Agricultural University of Athens with a number of studies the aim of which was to identify the production and reproductive traits with major economic impact, i.e. to define the breeding objective (LIANOS, 1986; PAPAVASILIOU et al., 1991). In those studies, the economically most important traits identified were: the number of pigs weaned per sow per year, the feed conversion ratio, the daily gain and the proportion of commercial meat cuts. Later on, ROGDAKIS et al. (1994) defined a breeding objective for fattening pigs which comprised the traits: proportion of commercial meat cuts, feed conversion ratio, and age at slaughter. Selection was based on an index including two selection criteria: (i) the weight corrected ratio between back fat thickness and depth of muscle $M$. longisimus dorsi and (ii) the weight corrected age of pigs at measurement. In those studies, however, estimates of genetic parameters of various traits were taken from the literature. Literature estimates cannot necessarily reflect the genetic potential of the breeding stock used, especially when the following are considered: first, the breeding stock is developed by a limited number of breeding animals imported in the farm in 1989 and thus could be subjected to the founder effect. Second, the breeding stock is kept under different production conditions (climate, nutrition regime etc) than in the countries of origin, e.g. Denmark. Reliable and specific population parameter estimates of heritabilities and genetic correlations of production and reproductive traits are essential in predicting breeding values accurately as well as in developing efficient breeding schemes. The method of restricted maximum likelihood (REML) applied to an individual animal model has been the widely used method for estimating variance components in animal populations, mainly because of its ability to account for selection and non-random mating when the complete variance covariance matrix of animal effects is known and used (KENNEDY et al., 1988; IM et al. 1989). The aim of this study is to estimate the genetic parameters for some production and reproductive traits in on a farm tested Landrace and Large White swine using single and multiple trait animal models and to propose efficient selection strategies.

\section{Material and Methods}

Data

Data regarding production traits were obtained between December 1992 and December 1996 in a breeding unit near Korinth comprising Large White (LW) and Landrace (LD) swine. During this period a total of 1332 LW and 1244 LD boars and gilts were measured for production traits using an ultrasound equipment (ALOKA SSD-500). Pigs were measured on discontinuous time lags. Pigs were housed in pens of about 10 animals and fed ad libitum during the whole test period. The test started at 140 days of age and ended at the age of 180 days. Pigs were weighed and backfat thickness and $M$. longisimus dorsi depth was measured on three points as described by ROGDAKIS et al. (1994). The traits studied were: age on measurement, average backfat thickness (BT: mean of three measurements), average muscle depth (MD: mean of three measurements) and $\mathrm{BT} / \mathrm{MD}$ ratio. Age, BT, $\mathrm{MD}$ and $\mathrm{BT} / \mathrm{MD}$ were adjusted to $85 \mathrm{~kg}$ liveweight using linear regression coefficients obtained by solutions of least squares equations (Table 2). Furthermore, reproductive traits for sows of both 
breeds were recorded from August 1989 to October 1995. These traits were: number of pigs born (NB) and number of pigs weaned (NW) per sow and parity. Repeated records per sow were available for both reproductive traits allowing the estimation of repeatabilities. The structure of the data sets analysed is shown in Table 1.

Table 1

Data structure of the production and reproductive traits (Datenstruktur fur die Produktions- und Reproduktionsmerkmale)

\begin{tabular}{lcc}
\hline & Landrace & Large White \\
\hline Production traits & & \\
Number of pigs tested & 693 & 631 \\
males & 636 & 609 \\
females & 1329 & 1240 \\
total & 48 & 48 \\
$\quad$ Number of year x sex x seasons effects & & 367 \\
Reproductive traits & 1540 & 115 \\
Number of records & 360 & 3.2 \\
Number of sows & 4.3 & 28 \\
Average number of records per sow & 28 & \\
Number of year x seasons effects & & \\
\hline
\end{tabular}

Table 2

Regression coefficients and standard errors (in parenthesis) of production traits corrected to $85 \mathrm{~kg}$ liveweight; all coefficients are statistically different from zero $\mathrm{p} \leq 0.001$ (Regressionskoeffizienten und Standardfehler (in Klammern) zur Korrektur der Produktionsmerkmale auf ein konstantes Korpergewicht von $85 \mathrm{~kg}$; alle Koeffizienten sind statistisch signifikant $\mathrm{p} \leq 0.001$ )

\begin{tabular}{lllll}
\hline Trait & $\begin{array}{l}\text { Landrace } \\
\text { Males }\end{array}$ & Females & $\begin{array}{l}\text { Large White } \\
\text { Males }\end{array}$ & Females \\
\hline Age $($ days $)$ & $1.0699(0.0257)$ & $1.1215(0.0258)$ & $1.0891(0.0261)$ & $1.1135(0.0268)$ \\
BT $(\mathrm{cm})$ & $0.0097(0.00037)$ & $0.0107(0.00037)$ & $0.0090(0.00038)$ & $0.0107(0.00039)$ \\
MD $(\mathrm{cm})$ & $0.0185(0.00064)$ & $0.0205(0.00064)$ & $0.0220(0.00065)$ & $0.0252(0.00067)$ \\
BT/MD & $0.00129(0.00009)$ & $0.00143(0.00009)$ & $0.00098(0.00009)$ & $0.00120(0.00009)$ \\
\hline BT: Backfat thickness; MD: Muscle depth & & &
\end{tabular}

\section{Univariate analysis}

Estimates of variance components for all traits studied were obtained using single-trait REML fitting an animal model and using a derivative-free algorithm. The model fitted for age, $\mathrm{BT}, \mathrm{MD}, \mathrm{BT} / \mathrm{MD}, \mathrm{NB}$ and $\mathrm{NW}$ in matrix notation was:

$$
y=X \beta+Z u+e
$$

where $\mathbf{y}$ is the vector of records on pigs or sows, $\boldsymbol{\beta}$ is the vector of fixed effects, $\mathbf{u}$ is a vector with elements the additive direct effects and e the vector of residuals. Furthermore, $\mathbf{X}$ and $\mathbf{Z}$ are the incidence matrices relating records to appropriate fixed and random effects, respectively. It is assumed that $\mathbf{E}(\mathbf{y})=\mathbf{X} \boldsymbol{\beta}, \mathbf{E}[\mathbf{u}]=\mathbf{E}[\mathbf{e}]=\mathbf{0}$ and $\operatorname{Cov}(\mathbf{u}, \mathbf{e})=\mathbf{0}$.

The assumed variance - covariance matrix of the random effects was as follows:

$$
\operatorname{Var}(y)=Z A Z^{\prime} \sigma_{a}^{2}+I \sigma_{e}^{2},
$$

where $\mathbf{A}$ is the numerator relationship matrix between animals and $\mathbf{I}$ an identity matrix of the order of the number of records. Furthermore, $\sigma_{a}^{2}$ and $\sigma_{e}^{2}$ are the additive gene- 
tic and the residual variance, respectively. Fixed effects fitted for fattening traits (age, BT, D and BT/MD) included year, season and sex. The importance of the fixed effects was identified by preliminary least squares analysis of variance of the traits studied. No breed by sex interaction was found to be important. Fixed effects for reproductive traits (NB and NW) included year, season and the parity number as a linear covariable. All pedigree information available was included in the analysis in order to minimize bias due to selection and to increase the accuracy of estimation. The calculations were carried out using the DFREML programs (MEYER, 1993) employing the Simplex procedure to locate the maximum of the log likelihood (L) as described by MEYER (1989). Convergence was considered to have been reached when the variance of function values was less than $10^{-8}$. In all the analyses, a restart was performed in an attempt to ensure that a global maximum had been reached. Repeatability estimates were obtained by fitting an animal model with correlated residuals (MEYER, 1993).

\section{Bivariate analyses}

Bivariate REML analyses were carried out to estimate genetic and phenotypic correlations between production and reproductive traits. Fixed effects for traits considered were as in univariate analyses. The model for the bivariate analysis was as that of univariate with the variance-covariance matrix for $y$ vector of observations defined to include genetic and residual covariances among the traits considered.

\section{Results \\ Breed and sex differences}

Means for production traits for the two breeds and for sexes within breeds are presented in Table 3. Males grew faster than females and showed smaller backfat thickness and muscle depths within the two breeds. Furthermore, LD grew faster than LW, were fatter and showed lower muscle depths. As a result, BT/MD ratio was

Table 3

Least squares means, standard errors of means (in parenthesis) and standard deviations (SD) of the production traits for the two breeds (LS-Mittelwerte, Standardfehler (in Klammern) und Standardabweichungen (SD) der Produktionsmerkmale bei beiden Rassen)

\begin{tabular}{|c|c|c|c|c|c|c|c|c|}
\hline & \multicolumn{2}{|c|}{ Age (days) } & \multicolumn{2}{|c|}{ BT (cm) } & \multicolumn{2}{|c|}{$\mathrm{MD}(\mathrm{cm})$} & \multicolumn{2}{|c|}{ BT/MD } \\
\hline & $\hat{\mu}$ & SD & $\hat{\mu}$ & SD & $\hat{\mu}$ & SD & $\hat{\mu}$ & SD \\
\hline Landrace (total) & $\begin{array}{l}158.9^{*} \\
(0.9)\end{array}$ & 19.1 & $\begin{array}{l}1.01^{*} \\
(0.01)\end{array}$ & 0.26 & $\begin{array}{l}4.44^{*} \\
(0.02)\end{array}$ & 0.45 & $\begin{array}{l}0.229^{*} \\
(0.003)\end{array}$ & 0.06 \\
\hline Males & $\begin{array}{l}156.6^{n} \\
(0.9)\end{array}$ & 18.0 & $\begin{array}{l}0.97^{\prime \prime} \\
(0.01)\end{array}$ & 0.21 & $\begin{array}{l}4.36^{\mathrm{a}} \\
(0.02)\end{array}$ & 0.44 & $\begin{array}{l}0.224^{\mathrm{a}} \\
(0.003)\end{array}$ & 0.05 \\
\hline Females & $\begin{array}{l}161.3^{b} \\
(1.0)\end{array}$ & 20.1 & $\begin{array}{l}1.05^{\mathrm{b}} \\
(0.01)\end{array}$ & 0.30 & $\begin{array}{l}4.53^{\mathrm{b}} \\
(0.02)\end{array}$ & 0.44 & $\begin{array}{l}0.233^{\mathrm{b}} \\
(0.004)\end{array}$ & 0.07 \\
\hline Large White (total) & $\begin{array}{l}160.7^{*} \\
(0.9)\end{array}$ & 20.1 & $\begin{array}{l}0.98^{4} \\
(0.01)\end{array}$ & 0.24 & $\begin{array}{l}4.79^{*} \\
(0.02)\end{array}$ & 0.46 & $\begin{array}{l}0.206^{*} \\
(0.003)\end{array}$ & 0.05 \\
\hline Males & $\begin{array}{l}159.5^{\mathrm{c}} \\
(1.0)\end{array}$ & 20.3 & $\begin{array}{l}0.91^{\mathrm{c}^{\prime}} \\
(0.01)\end{array}$ & 0.20 & $\begin{array}{l}4.67^{\circ} \\
(0.02)\end{array}$ & 0.45 & $\begin{array}{l}0.197^{c} \\
(0.003)\end{array}$ & 0.05 \\
\hline Females & $\begin{array}{l}161.9^{b} \\
(1.0)\end{array}$ & 20.0 & $\begin{array}{l}1.05^{6} \\
(0.01)\end{array}$ & 0.25 & $\begin{array}{l}4.91^{d} \\
(0.02)\end{array}$ & 0.44 & $\begin{array}{l}0.215^{d} \\
(0.004)\end{array}$ & 0.04 \\
\hline
\end{tabular}

Means with different letters as superscripts are statistically significantly different $(p<0.05)$

Breed means are statistically significantly different ( $p \leq 0.005)$ 
Arch. Tierz, $43(2000) 3$

Table 4

Least squares means, standard errors of means (in parenthesis) and standard deviations (SD) of the reproductive traits for the two breeds (LS-Mittelwerte, Standardfehler (in Klammern) und Standardabweichungen (SD) der Reproduktionsmerkmale bei beiden Rassen)

\begin{tabular}{lllll}
\hline \multirow{2}{*}{ Trait } & $\hat{\mu}$ & \multicolumn{2}{c}{ Landrace } & Large White \\
& & SD & $\hat{\mu}$ & SD \\
\hline Number of pigs born & $10.942^{\mathrm{a}}(0.073)$ & 2.82 & $11.525^{\mathrm{b}}(0.152)$ & 2.92 \\
Number of pigs weaned & $9.363^{\mathrm{a}}(0.048)$ & 2.18 &, $9.200^{\mathrm{a}}(0.10)$ & 2.01 \\
Average age of sows (years) & $2.24^{\mathrm{a}}(0.02)$ & 0.96 & $2.20^{\mathrm{a}}(0.06)$ & 1.06 \\
\hline Means with different letters in superscripts are statistically significantly different (p $\leq .005)$ &
\end{tabular}

higher in LD than in LW. Means for the reproductive traits are shown in Table 4. LW had bigger litters at birth than LD. No breed difference for litter size at weaning was found. Average age of sows between breeds was not statistically different $(p \leq 0.005)$. Standard deviations for the production traits age and MD were comparable along breeds and sexes resulting in coefficients of variation in the range of $10-13 \%$. On the contrary, standard deviation of BT was higher resulting in higher coefficients of variation $(20-30 \%)$ for this trait. The coefficients of variation of BT/MD followed therefore the same pattern. Standard deviations for the reproductive traits were comparable across the two breeds. The resulting coefficients of variation for these traits were in the range of $23-25 \%$.

\section{Heritabilities}

Variance components and heritabilities from univariate analysis for the production traits are shown in Table 5. Age at $85 \mathrm{~kg}$ was found more heritable in LD (0.60) than in LW (0.36). Both breeds showed the same heritability for backfat thickness (0.44). On the contrary, muscle depth was found more heritable in LD (0.51) than in LW (0.37). Heritabilities for BT/MD ratio were almost the same in both breeds. Variance components, heritabilities and repeatabilities for the reproductive traits are presented in Table 6. Number of pigs born was found more heritable than number of pigs weaned (NW) in both breeds. Heritabilitiy of NB in LW sows was lower than in LD. Very small estimates (0.03) for heritability were obtained for NW in both breeds. Repeatabilities followed the pattern of heritabilities with estimates for NB and NW of 0.30 and 0.10 in LD and of 0.10 and 0.05 , in LW, respectively.

Table 5

Estimates of variance components and heritabilities for production traits in Landrace (LD) and Large White (LW) pigs (Varianzkomponenten- und Heritabilitătsschătzung fur die Produktionsmerkmale bei Landrasse und den Large White)

\begin{tabular}{lllllllll}
\hline & \multicolumn{2}{c}{$\sigma_{a}^{2}$} & \multicolumn{2}{c}{$\sigma_{e}^{2}$} & \multicolumn{2}{c}{$\sigma_{P}^{2}$} & \multicolumn{2}{c}{$h_{a}^{2}$} \\
& LD & LW & LD & LW & LD & LW & LD & LW \\
\hline AGE & 119.0 & 84.5 & 79.7 & 152.8 & 198.7 & 237.5 & $0.60 \pm 0.05$ & $0.36 \pm 0.06$ \\
BT & 0.021 & 0.018 & 0.027 & 0.023 & 0.048 & 0.041 & $0.44 \pm 0.06$ & $0.44 \pm 0.07$ \\
MD & 0.076 & 0.049 & 0.073 & 0.084 & 0.149 & 0.132 & $0.51 \pm 0.06$ & $0.37 \pm 0.07$ \\
BT/MD & 0.0013 & 0.0010 & 0.0018 & 0.0013 & 0.0030 & 0.0023 & $0.42 \pm 0.06$ & $0.45 \pm 0.07$ \\
\hline
\end{tabular}

$\sigma_{a}^{2}$; additive genetic variance; $\sigma_{e}^{2}:$ error variance; $\sigma_{P}^{2}$ : phenotypic variance; $h_{a}^{2}$ heritability

BT: Backfat thickness; MD: Muscle depth 
Table 6

Estimates of variance components and heritabilities for reproductive traits in Landrace (LD) and Large White (LW) sows (Varianzkomponenten- und Heritabilitătsschătzung für die Reproduktionsmerkmale bei den Landrasse- und Large White-Sauen)

\begin{tabular}{|c|c|c|c|c|}
\hline \multirow[t]{2}{*}{ Trait } & \multicolumn{2}{|c|}{ NB } & \multicolumn{2}{|c|}{ NW } \\
\hline & LD & LW & LD & LW \\
\hline$\sigma_{a}^{2}$ & 1.920 & 1.072 & 0.098 & 0.053 \\
\hline$\sigma_{p e}^{2}$ & 0.422 & 0.912 & 0.246 & 0.108 \\
\hline$\sigma_{e}^{2}$ & 5.727 & 7.385 & 2.810 & 3.299 \\
\hline$\sigma_{P}^{2}$ & 7.648 & 8.457 & 3.154 & 3.352 \\
\hline$h_{a}^{2}$ & $0.25 \pm 0.03$ & $0.13 \pm 0.06$ & $0.03 \pm 0.02$ & $0.02 \pm 0.05$ \\
\hline$r$ & 0.30 & 0.24 & 0.10 & 0.05 \\
\hline
\end{tabular}

$\sigma_{a}^{2}$ : additive genetic variance; $\sigma_{e}^{2}$ : error variance; $\sigma_{p e}^{2}$ : permanent environmental variance; $\sigma_{p}^{2}$ : phenotypic variance; $h_{a}^{2}:$ heritability, r: repeatability; NB: number of pigs born per litter; NW: number of pigs weaned per litter

Table 7

Genetic (above diagonal) and phenotypic (below diagonal) correlations of the various production and reproductive traits in Landrace (LD) and Large White (LW) pigs; numbers on the diagonal are average heritability estimates from the bivariate analyses (Genetische (oberhalb der Diagonale) und phannotypische (unterhalb der Diagonale) Korrelationen der Produktions- und Reproduktionsmerkmale bei Landrasse- und Large White-Schweinen; Werte auf der Diagonale sind durchschnittliche Heritabilitătsschătzungen aus der Bivariatanalyse)

\begin{tabular}{|c|c|c|c|c|c|c|c|c|}
\hline \multirow{2}{*}{ Trait } & \multicolumn{2}{|c|}{1} & \multicolumn{2}{|c|}{2} & \multicolumn{2}{|c|}{3} & \multicolumn{2}{|c|}{4} \\
\hline & LD & LW & LD & LW & LD & LW & LD & LW \\
\hline \multicolumn{9}{|l|}{ Production } \\
\hline 1. AGE & $(0.54)$ & $(0.39)$ & -0.22 & -0.44 & -0.03 & -0.05 & -0.16 & -0.40 \\
\hline 2. BT & -0.10 & -0.19 & $\begin{array}{l} \pm 0.08 \\
(0.40)\end{array}$ & $\begin{array}{l} \pm 0.08 \\
(0.48)\end{array}$ & $\begin{array}{l} \pm 0.06 \\
-0.36\end{array}$ & $\begin{array}{l} \pm 0.09 \\
-0.25\end{array}$ & \pm 0.09 & \pm 0.08 \\
\hline 3. $\mathrm{MD}$ & -0.02 & -0.02 & -0.17 & -0.12 & $\begin{array}{l} \pm 0.07 \\
(0.55)\end{array}$ & $\begin{array}{l} \pm 0.08 \\
(0.40)\end{array}$ & & \\
\hline 4. BT/MD & -0.08 & -0.18 & & & & & $(0.40)$ & $(0.48)$ \\
\hline Reproductive & & & & & & & & \\
\hline 1. NB & $(0.27)$ & $(0.15)$ & 0.46 & 0.70 & & & & \\
\hline 2. NW & 0.89 & 0.67 & $\begin{array}{l} \pm 0.11 \\
(0.03)\end{array}$ & $\begin{array}{l} \pm 0.35 \\
(0)\end{array}$ & & & & \\
\hline
\end{tabular}

BT: Backfat thickness; MD: Muscle depth; NB: number of pigs born per litter; NW: number of pigs weaned per litter

\section{Correlations}

Table 7 summarizes the phenotypic and genetic correlations between the production and reproductive traits. Correlations between $\mathrm{BT}$ and $\mathrm{MD}$ with $\mathrm{BT} / \mathrm{MD}$ are not presented, because the single traits are autocorrelated to their ratio. Age at $85 \mathrm{~kg}$ was found negatively genetically correlated to all other production traits. This negative correlation was more evident in LW than in LD for the traits age - BT and age $\mathrm{BT} / \mathrm{MD}$. Genetic correlation between age and $\mathrm{MD}$ was found negative and close to zero. Backfat thickness was found genetically negatively correlated to MD in both breeds. This correlation was higher in LD than in LW. Phenotypic correlations between traits were generally smaller than the respective genetic correlations in both breeds. A high genetic correlation was obtained between NB and NW in both breeds. 
On the contrary to production traits, phenotypic correlations for reproductive traits were higher than the genetic correlations.

\section{Discussion \\ Breed and sex differences}

The present results show a significant breed and sex effect on production traits. Landrace pigs grew faster, were fatter and showed smaller muscle depths than LW. The result about the age is not in agreement with other literature references where LW are generally reported to grow faster than Landrace pigs (GU et al., 1989, FERRAZ and JOHNSON, 1993; BIDANEL et al., 1994; DUCOS and BIDANEL, 1996). Furthermore, LD pigs are reported to be leaner (GU et al., 1989) or fatter at standardized liveweight (FERRAZ and JOHNSON, 1993; BIDANEL and DUCOS, 1996; DUCOS and BIDANEL, 1996) as in the present study. Since the animals of the present study were kept under the same environmental conditions the observed differences may reflect strain differences of the breeds used. Comparison of the two breeds for the reproductive performance showed a higher number of pigs born in LW sows than in LD. No difference between the two breeds for number of pigs weaned was observed. Bigger litter sizes at birth for LW sows are also reported in the literature (FERRAZ and JOHNSON, 1993; DUCOS and BIDANEL, 1996). On the contrary, ROEHE and KENNEDY (1995) found no difference for litter size at birth and at weaning between Yorkshire and LD sows.

\section{Heritabilities}

Heritabilities for the production traits were high, ranging from 0.37 to 0.60 . Reported heritabilities for these traits are in the range of 0.21 to 0.59 for LD and 0.21 to 0.53 for LW (KENNEDY et al., 1985; SAVOIE and MINVIELLE, 1988; GU et al., 1989; KAPLON et al., 1991; HOVENIER et al., 1992; LO et al., 1992; BRYNER et al., 1992; BIDANEL et al., 1994; LI and KENNEDY, 1994; DUCOS and BIDANEL, 1996; BRANDT and TAEUBERT, 1998). Selection on production traits has proved to be efficient in both breeds. HUDSON and KENNEDY (1985) and KENNEDY et al. (1986) reported a genetic change of age to $90 \mathrm{~kg}$ in Canadian populations in the range from -0.25 to -0.44 days per year. FERRAZ and JOHNSON (1993) estimated a genetic trend of $-0.063 \mathrm{~mm}$ per year for backfat thickness. KENNEDY et al. (1996) found that the annual genetic trends over the years 1976 to 1993 for 4 breeds (LD, LW, Duroc and Hampshire) and 4 regions in Canada were $-1.44 \%$ and $-0.36 \%$ for the mean in fat depth and in age at $100 \mathrm{~kg}$, respectively.

Heritability of NB was found higher in LD than in LW sows. The value estimated in LD $(0.25)$ is out of the range (0.02 to 0.18$)$ reported from KAPLON et al. (1991), FERRAZ and JOHNSON (1993), SEE et al. (1993), ROEHE and KENNEDY (1995) and from DUCOS and BIDANEL (1996). On the contrary, values close to zero $(0.03)$ were obtained for the heritabilities of NW in both breeds. These values are also out of the range $(0.06$ to 0.08$)$ which is reported in the literature for heritability of NW (KAPLON et al., 1991; ROEHE and KENNEDY, 1995). This result indicates that selection for reproductive performance should concentrate on NB. Selection on this 
BIZELIS et al.: Genetic parameters of production and reproductive traits in on a tested swine in Greece

trait has also proved to be efficient in the literature. FERRAZ and JOHNSON (1993) estimated a genetic trend of 0.012 pigs per year for litter size at birth.

\section{Correlations}

Genetic correlations between some production traits were found negative in both breeds. The highest values were obtained between age and BT in LW $(-0.44)$ and between BT and MD in LD (-0.36). Negative genetic correlations between age and BT are reported widely in the literature in the magnitude of -0.05 to -0.54 in both breeds (JEFFRIES and PETERSON, 1982; KENNEDY et al., 1985; SAVOIE and MINVIELLE, 1988; KAPLON et al., 1991; HOFER et al., 1992; LO et al., 1992; BIDANEL et al., 1994; LI and KENNEDY, 1994). Negative genetic correlations between BT and MD are found also by LO et al. (1992). Furthermore, backfat thickness is reported to be highly correlated $(-0.52$ to -0.99$)$ to premium cuts in proportion to carcass weight (SCHWOERER et al., 1980; BLUM et al., 1984; BERESKIN and STEELE, 1988). Also muscle area of longissimus dorsi is reported to be correlated $(0.80)$ with commercial meat cuts (BERESKIN and STEELE, 1988). High correlations of backfat thickness and (or) of the M. longissimus dorsi area with commercial meat cuts imply their potential use as selection criteria for genetically improving commercial meat cuts. The latter is a trait with major economic impact for the Greek pig industry (PAPAVASILIOU et al., 1991).

Genetic correlations between the reproductive traits NB and NW were found high ( 0.46 to 0.70$)$ in this study. Since heritability of NW was close to zero but that of NB was relatively high, selection on NB will result in an increase of the NW as a correlated response. Number of pigs weaned is a trait with great commercial importance for Greek pig industry (PAPAVASILIOU et al., 1991).

High genetic correlations between those traits are also reported in the literature. ROEHE and KENNEDY (1995) found a genetic correlation between NB and NW of 0.65 in LW and of 0.82 in LD sows. KAPLON et al. (1991) reported genetic and phenotypic correlation for litter size at birth and litter size at 21 days of 0.91 and 0.88 , respectively.

The estimation of reliable genetic correlations between production and reproductive traits was not feasible in the present study due to lack of adequate number of records for both production and reproductive traits. However, the analysis of a pooled data set (of both breeds) obtained by limited number of records for both production and reproductive traits showed very small $(0.05$ to 0.20$)$ and divergent (favorable or unfavorable) genetic correlations between production and reproductive traits. The hypothesis of no genetic correlation between production and reproductive traits has been repeatedly supported in the literature (HALEY et al., 1988; RYDHMER et al., 1995; DUCOS and BIDANEL, 1996). There is some evidence, however, that traits like ovulation rate, number of embryos and embryo survival at 30 days of gestation be low but favorably correlated with litter weight at birth, with average daily gain between 30 and $85 \mathrm{~kg}$ and average backfat thickness (BIDANEL et al., 1996). HALEY and LEE (1992) have also reported high and positive genetic correlation between ovulation and litter weight at birth. The use of such traits as selection criteria, however, cannot be always envisaged under farm conditions. On the contrary, weight traits like 
litter weight at birth or at weaning could easily and at low costs be measured. In a divergent selection experiment for lean growth capacity in a population of LW pigs, KERR and CAMERON (1996) found that the genetic correlations of litter weight at birth and at weaning with daily food intake were positive and relatively high ( 0.42 to 0.50 ). The corresponding correlations with backfat thickness were, however, not significantly different from zero.

\section{Selection strategy}

The high heritabilities obtained for the production traits in the present study, ensured that the imported breeding stock which was used for the establishment of the herd originated from genetically diverse animals. Therefore, selection for leaner, fast growing pigs is expected to be efficient in both breeds. Besides the demand of the market for leaner pork at low prices, increasing attention is paid by both producers and consumers to meat quality aspects, i.e. meat color, water binding capacity, $\mathrm{pH}$ and intramuscular fat content, as well. Moderate to high heritabilities for meat quality traits are often reported in the literature (CAMERON, 1990; LO et al., 1992; HOVENIER et al., 1992) so selection on those traits is expected to be efficient. Alternatively, improved pork meat quality could be attained if those traits were correlated to other, easy to measure, traits. HOVENIER et al. (1992) reported favorable genetic correlations between liveweight gain and meat quality traits and unfavorable genetic correlations between meat quality traits and backfat thickness and lean meat content. Slightly unfavorable genetic correlations between $\mathrm{pH}$ and age or between $\mathrm{pH}$ and BT are also reported in the literature (JOHANSSON, 1987; BIDANEL et al., 1994). Furthermore, CAMERON (1990) and LO et al. (1992) have found unfavorable genetic correlations between muscle depth and (or) backfat thickness with intramuscular fat content and water holding capacity. Eventually, selection for faster growing and leaner pigs is expected to lower meat quality resulting in pork meat less juicy, tender and with less flavor. Selection for more efficient pigs should therefore include aspects of meat quality as well. This implies the need of the inclusion of one, at least, meat quality trait, for instance $\mathrm{pH}$ and (or) intramuscular fat content, as a selection criterion, as well. Alternatively, meat quality could be retained unchanged by the use of restriction selection indices.

\section{References}

BERESKIN, B.; STEELE, N. C.: Estimates of genetic parameters for carcass measures of body composition and growth in swine. J. Anim. Sci. 66 (1988), 2498-2507

BIDANEL, J. P.; DUCOS, A.; GUEBLEZ, R.; FABROUE, F.: Genetic parameters of backfat thickness, age at $100 \mathrm{~kg}$ and ultimate $\mathrm{pH}$ in on-farm tested French Landrace and Large White pigs. Livest. Prod. Sci. 40 (1994), 291 - 301

BIDANEL, J. P.; DUCOS, A.: Genetic correlations between test station and on-farm performance traits in Large White and French Landrace pig breeds. Livest. Prod. Sci. 45 (1996), 55-62

BIDANEL, J. P.; GRUNAND, J.; LEGAULT, C.: Genetic variability of age and weight at puberty, ovulation rate and embryo survival in gilts and relationship with production traits. Gen. Sel. Evol. 28 (1996), 103 - 115

BLUM, J. K.; REBSAMEN, A.; SCHWOERER, D.: Die Berechnung des Selektionsindexes der MLP Sempach. Kleinviehzuchter, 32 (1984), 1266-1283 
BRANDT, H.; TÄUBERT, H.:

Parameter estimates for purebred and crossbred performances in pigs. J. Anim. Breed. Genet. 115 (1998), 97-104

BRYNER, S. M.; MARBY, J. V.; BERTRAND, J. K.; BENYSHEK L. L. ; KRIESE, L. A.:

Estimation of direct and maternal heritability and genetic correlation for backfat and growth rate in swine using data from centrally tested Yorkshire boars. J. Anim. Sci. 70 (1992), 1755-1759

CAMERON, N.D.:

Genetic and phenotypic parameters between carcass traits, meat and eating quality traits in pigs. Livest. Prod. Sci. 26 (1990), $119-135$

DUCOS, A.; BIDANEL, J. P.:

Genetic correlations between production and reproductive traits measured on the farm, in the Large White and French Landrace pig breeds. J. Anim. Breed. Genet. 113 (1996), 493-504

HALEY, C. S.; AVALOS, E; SMITH, C.:

Selection for litter size in the pig. Anim. Breed. Abstr. 56 (1998), 317 - 325

HALEY, C. S.; LEE, G. J.:

Genetic factors contributing to variation in litter size in British Large White gilts. Livest. Prod. Sci. 30 (1992), $99-113$

HOFER, A.; HAGGER, C.; KEUNZI, N.:

Genetic evaluation of on-farm tested pigs using an animal model. I. Estimation of variance components with restricted maximum likelihood. Livest. Pod. Sci. 30 (1992), 69-82

HUDSON, G. F. S.; KENNEDY, B. W.:

Genetic trend of growth rate and backfat thickness of swine in Ontario. J. Anim. Sci. 61 (1985), 92 - 97

HOVENIER, R.; KANIS, E.; VAN ASSELDONK, T.; WESTERINK, N. G.:

Genetic parameters of pig meat quality traits in a halothane negative population. Livest. Prod. Sci. 32 (1992), 309-321

GU, Y.; HALEY, C. S.; THOMPSON, R.:

Estimates of genetic and phenotypic parameters of growth and carcass traits from closed lines of pigs on restricted feeding. Anim. Prod. 49 (1989), 467-475

FERRAZ, J. B. S.; JOHNSON, R.:

Animal model estimation of genetic parameters and response to selection for litter size and weight, growth and backfat in closed seedstock polulations of Large White and Landrace swine. J. Anim. Sci. 71 (1993), 850-858

IM, S.; FERNANDO, R. L.; GIANOLA, D.:

Likelihood inferences in animal breeding under selection: a missing data theory view point. Genet. Sel. Evol. 21 (1989), 399-414

JEFFRIES, D. C.; PETERSON, R. G.:

Heritabilities and genetic correlations for ultrasonic backfat measurements, growth and carcass traits in swine. Can. J. Anim. Sci. 62 (1982), 665-670

JOHANSSON, K.:

Evaluation of station testing of pigs. II. Multiple trait versus single trait estimation of genetic parameters for meat quality measurements. Acta Agric. Scand. 37 (1987), 108-119

KAPLON, M. J.; ROTHSCHILD, M. F.; BERGER, P. J.; HEALEY, M.:

Population parameter estimates for performance and reproductive traits in Polish Large White nucleus herds. J. Anim. Sci. 69 (1991), 91-98

KENNEDY, B.W.; JOHANSSON, K.; HUDSON, G. F. S.:

Heritabilities and genetic correlations for backfat and age at $90 \mathrm{~kg}$ in performance tested pigs. J. Anim. Sci. 65 (1985), 78-82

KENNEDY, B. W.; HUDSON, G. F.S.; SCHAEFFER, L. R.:

Evaluation of the genetic change in performance tested pigs in Canada. Proc. 3rd World Congr. Genet. Appl. Livest. Prod., Lincoln, vol. X (1986), 149-154

KENNEDY, B. W.; SCHAEFFER, L.R.; SORENSEN, D. A.: Genetic properties of animal models. J. Dairy Sci. 71 (1988). Suppl. 2, 17-26

KENNEDY, B. W.; QUINTON, V. M.; SMITH, C.:

Genetic changes in Canadian performance tested pigs for fat depth and growth rate. Can. J. Anim. Sci. 76 (1996), 41-48

KERR, J. C.; CAMERON, N. D.:

Genetic and phenotypic relationships between performance test and reproduction traits in Large White pigs. Animal Science 62 (1996), 531- 540 
LAMBERSON, W. R.; JOHNSON, R. K.; ZIMMERMAN, D. R.; LONG, T. E.:

Direct responses to selection for increased litter size, decreased age at puberty, or random selection LIANOS, N.:

following selection for ovulation rate in swine. J. Anim. Sci. 69 (1991), 3129-3143

Selection planning of pigs in Greece. Dissertation. Agric, 1986, University of Athens.

LI, X.; KENNEDY, B. W.:

Genetic parameters for growth rate and backfat in Canadian Yorkshire, Landrace, Duroc and Hampshire pigs. J. Anim. Sci. 72 (1994), 1450 - 1454

LO, L. L.; MC LAREN, D. G.; MC KEITH, F. K.; FERNANDO, R. L.; NOVAKOFSKI, J.:

Genetic analysis of growth, real-time ultrasound, carcass and pork quality traits in Duroc and Landrace

MEYER, K.: pigs: II. Heritabilities and correlations. J. Anim. Sci. 70 (1993), 2387-2396

Restricted maximum likelihood to estimate variance components for animal models with several MEYER, K.: random effects using a derivate free algorithm. Genet. Select. Evol. 21 (1989), 317 - 340

DFREML. User Notes. Version 2.1., 1993

PAPAVASILIOU, D.; APOSTOLOPOULOS, K.; ROGDAKIS, E.:

Economic weights for the main characteristics in Greek pig production. Animal Science Review 13 (1991), 75-91

ROEHE, R.; KENNEDY, B. W.:

Estimation of genetic parameters for litter size in Canadian Yorkshire and Landrace swine with each parity of farrowing treated as a different trait. J. Anim. Sci. 73 (1995), 2959- 2970

ROGDAKIS, E.; BIZELIS, J.; KOMINAKIS, A.; PAPAVASILIOU, D.; MALIAPPIS, M.; GEORGADOPOULOU, F.:

Ultrasonic fat and muscle depth measurements in pig: repeatability and implementation in the selection process. Animal Science Review 19 (1994), 5-19

RYDHMER, L.; LUDEHEIM, N.; JOHANSSON, K.:

Genetic parameters for reproduction traits in sows and relations to performance - test measurements. $\mathrm{J}$. Anim. Breed. Genet. 112 (1995), 33-42

SATHER, A.P.; BAILEY, D. R.; JONES, S. D. M.:

Real-time ultrasound image analysis for the estimation of carcass yield and pork quality. Can. J. Anim. Sci. 76 (1996), 55-62

SAVOIE, Y.; MINVIELLE, F.:

Etude sur les porc de race controles a la ferme au Quebec. 2. Estimation des parametres genetiques et phenotypiques. Can. J. Anim. Sci. 68 (1988), 1063 - 1068

SCHWOERER, D.; BLUM, J.; REBSAMEN, A.:

Parameters of meat quality and stress resistance of pigs. Livest. Prod. Sci. 7 (1980), 337-348.

SEE, M. T.; MARBY, J. W.; BERTRAND, J. K.:

Restricted maximum likelihood estimation of variance components from field data for number of pigs born alive. J. Anim. Sci. 71 (1993), 2905-2909

Received: 1999-03-22

Accepted: $1999-11-19$

Authors' address

Dr. JOSEF BIZELIS, Dr. ANTONIOS KOMINAKIS, Prof. Dr. EMMANUEL ROGDAKIS,

Dipl. Agraring. FOTINI GEORGADOPOUOLOU

Department of Animal Breeding and Husbandry, Faculty of Animal Science,

Agricultural University of Athens,

Iera Odos 75, 11855, Athens

Greece 
Arch. Tierz., Dummerstorf 43 (2000) 3, 298

\title{
Buchbesprechung
}

\author{
Deutsche Holsteins - Die Geschichte einer Zucht -
}

\author{
B. MÜGGE, W. E. LUTZ, H. SÜDBECK, S. ZELFEL
}

1. Auflage, 147 Seiten, 51 Tabellen, 37 Farb- und 87 Schwarz-Weiß Fotos, Verlag Eugen Ulmer, Stuttgart, 1999, ISBN-Nr. 3-8001-4538-3, 78,- DM

In dem faszinierenden Buch wird die Entwicklung einer Rasse in nahezu 125 Jahren von sehr kompetenten Autoren übersichtlich dargestellt. In unserer schnelllebigen Zeit ist es besonders wichtig, dass die Entwicklungsschritte dieser erfolgreichen Rinderrasse festgehalten und dargestellt werden. Dies ist gleichzeitig eine besondere Ehre für diejenigen, die sich tatkräftig und uberzeugend für diese Rasse engagierten. Die Abhandlung der Thematik erfolgt in fünf Kapiteln. Im ersten Kapitel werden die Anfänge einer systematischen Züchtung für Milchrinder in Deutschland von 1850 bis zum 1. Weltkrieg ubersichtlich dargestellt. Gerade die junge Generation kann die historische Entwicklung von den Landschlägen hin zu den regionalen Zuchtrichtungen gut nachvollziehen.

Das zweite Kapitel veranschaulicht sehr eindrucksvoll die Konsolidierung der Rassen und den Zusammenbruch am Ende des 2. Weltkrieges, d.h. den Zeitabschnitt von 1919 bis 1945.

In diesem Zeitraum entwickelten sich leistungsfähige Zuchtverbănde und Persönlichkeiten, wie Adolf Köppe (Ostfriesland) und Jakob Peters (Ostpreußen), bestimmten die Ausrichtung auf Leistung und Vermarktung.

Nach dem zweiten Weltkrieg begann der Aufbau einer stark geschrumpften Schwarzbuntpopulation, die, insbesondere durch den Verlust der hervorragenden ostdeutschen Zuchtgebiete, einen mulhsamen Weg bis 1960 beschritt. Von 1960 bis zur Wende (Kap. 4) entwickelten sich zwei unterschiedliche Schwarzbuntzuchten in Deutschland. Wăhrend die DDR sich voll auf Kreuzungszucht konzentrierte und das Schwarzbunte Milchrind (SMR) fulr die Großbetriebe zulchtete, setzte das Zuchtprogramm in der Bundesrepublik auf eine Verdrängungszucht mit Holstein-Friesian aus Nordamerika. Die Zeit von „Pabst Ideal“ begann in Deutschland und unterstützt durch die Förderung von $\mathrm{H}$. Wilhelm Schaumann wurde die wissenschaftliche Begleitung der Einkreuzung møglich.

Das letzte Kapitel beschreibt die Entwicklung nach der Wiedervereinigung. Neue Organisationen bilden Zuchteinheiten, die uber Lăndergrenzen hinweg arbeiten und damit den zukünftigen Entwicklungen eines globalisierten Marktes gewachsen sein werden.

Das interessante und gut aufgemachte Buch ist eine sehr gelungene Darstellung der Entwicklung der Milchviehzucht in Deutschland. Es ist ein Standardwerk für jeden engagierten Zuchter. Die interessante Dokumentation der Zuchtgeschichte am Beispiel der Deutschen Holstein zeigt die Möglichkeiten der Auswirkung von additiven Geneffekten durch die Verdrăngungszucht, doch ob die Reinzucht die Zuchtmethode bei der Weiterentwicklung der Rinderzucht bleiben wird, bleibt abzuwarten. 